\title{
Jakub Lampart
}

Uniwersytet Jagielloński

(D) https://orcid.org/0000-0002-8208-2833

\section{Społeczne funkcjonowanie wiedzy i nauki w filozofii Paula Feyerabenda - ideologie, interakcje i kosmologie}

\section{The Social Functioning of Knowledge and Science in the Philosophy of Paul Feyerabend - Ideologies, Interactions, and Cosmologies}

\begin{abstract}
In his article, Jakub Lampart addresses the social, cultural, and historical functions of various forms of knowledge (and of science in particular) as they can be reconstructed on the basis of the few descriptive remarks found in Paul Feyerabend's works in the three periods of his scholarly career: moderate, transitional, and radical. Lampart interprets Feyerabend's views on the relationship between knowledge and society as influenced by the following: the early concepts of Karl Popper (in the moderate period), some of the theses of Benjamin L. Whorf and the late Ludwig Wittgenstein (in the radical period). The article also contains: a) a juxtaposition of Feyerabend's views with the theories of these thinkers; (b) an attempt to explain Feyerabend's use of the term "ideology"; (c) a description of two trends characterizing different systems of knowledge: isolation and interaction; d) a description of the two types of ideal members of a given tradition: rationalists and pragmatists.
\end{abstract}

Keywords: Feyerabend, Whorf, late Wittgenstein, Popper, Kuhn

Celem niniejszego artykułu jest zrekonstruowanie deskryptywnej części zapatrywań Paula Karla Feyerabenda na relację społeczeństwa i wiedzy/nauki, obrazu tej relacji, jaki ukazuje się w nielicznych, rozproszonych i właśnie opisowych fragmentach prac filozofa. Znaczenie tytułowego ,społeczne” 
wyjaśniają najlepiej słowa Marka Siemka z Myśli drugiej połowy XX wieku: „wyróżnia ją to, że problematyka historyczności, uspołecznienia i kultury jest dla niej właśnie centralną i najzupełniej »ścisłą«, jeśli nie wręcz jedyną, problematyką myślenia filozoficznego w ogóle". Niech „społeczne” będzie skrótem od „społeczne, historyczne i kulturowe”. W istocie, w swoich szczątkowych analizach filozof płynnie porusza się między tymi trzema wymiarami. Choć myśl Feyerabenda bywała opisywana w kategoriach amodernizmu², którego twórca sprzeciwia się mówieniu o „społecznym kontekście”, nie sposób całkowicie uniknąć owego „społecznego funkcjonowania” nauki przy czytaniu amerykańskiego filozofa. Myśl Feyerabenda bowiem bliższa jest Teorii Aktora-Sieci niż koncepcje innych znanych filozofów i filozofek nauki, lecz pod pewnymi istotnymi względami lokuje się w "dawnym układzie”. W „okresie radykalnym” analizowany tutaj aspekt jego filozofii odczytuję w sposób, który mógłby przywołać na myśl choćby Mocny Program socjologii wiedzy ${ }^{3}$. Jeśli zaś szerzej rozumieć wojny o naukę, jak sugeruje to Bruno Latour ${ }^{4}$, Feyerabend niewątpliwie przewidywał rozsądne zaniechanie walki. Nie zmienia to jednak faktu, iż był jednym z jej najgłośniejszych uczestników. Należałoby jeszcze zarysować stosunek Feyerabenda do historii nauki, który Wojciech Sady określił jako niejasny ${ }^{5}$. Feyerabend niezobowiązująco przywołuje najrozmaitsze zajścia $\mathrm{z}$ historii różnych form wiedzy, by obrazować swoje ogólne tezy o interakcjach kultur i ich wewnętrznych procesach. Nie jest to więc „historia wewnętrzna”, ,racjonalna rekonstrukcja” (w sensie nadanym jej przez Imrego Lakatosa ${ }^{6}$ ), historia nauki w ujęciu francuskiej epistemologii ${ }^{7}$ czy inna systematyczna analiza.

${ }^{1}$ M. Siemek: Myśl drugiej połowy XX wieku. W: Drogi współczesnej filozofii. Wybrał i wstępem opatrzył M.J. Siemek. Przeł. S. Cichowicz et al. Czytelnik, Warszawa 1978, s. 46.

2 D. Mączka: Amodernistyczna filozofia Paula Feyerabenda. „Hybris” 2018, nr 41, s. 77-97. Pobrano z: https://ruj.uj.edu.pl/xmlui/bitstream/handle/item/56562/maczka_amodernistyczna_filozofia_paula_\%20feyerabenda_2018.pdf?sequence $=3 \&$ isAllowed $=y$ [23.11.2021].

${ }_{3}$ Por. B. Barnes, D. Bloor: Mocny program socjologii wiedzy. Przeł. Z. Jankiewicz. Wydawnictwo Instytutu Filozofii i Socjologii Polskiej Akademii Nauk, Warszawa 1993.

${ }^{4}$ Por. B. Latour: Nadzieja Pandory. Eseje o rzeczywistości w studiach nad nauka. Przeł. K. Abriszewski. Wydawnictwo Naukowe Uniwersytetu Mikołaja Kopernika, Toruń 2013.

${ }^{5}$ W. Sady: Spór o racjonalność naukowa. Od Poincarégo do Laudana. Wyd. 2., rozsz. i popr. Wydawnictwo Naukowe Uniwersytetu Mikołaja Kopernika, Toruń 2013, s. 343.

${ }^{6}$ I. Lakatos: Pisma z filozofii nauk empirycznych. Przeł. W. Sady. Wydawnictwo Naukowe PWN, Warszawa 1995, s. 170.

${ }^{7}$ Por. D. Leszczyński, K. Szlachcic: Wprowadzenie do francuskiej filozofii nauki. Od Comte'a do Foucaulta. Wydawnictwo Uniwersytetu Wrocławskiego, Wrocław 2003. 


\section{Okres umiarkowany i przejście do radykalnego}

\section{Racjonalizm krytyczny}

Pierwsze prace Feyerabenda poświęcone są prawie wyłącznie metodologii, motywy społeczne ujawniają się jedynie w nielicznych fragmentach, w których dominuje falsyfikacjonistyczne ujęcie relacji wiedzy i społeczeństwa. Należy więc krótko zarysować, jak zagadnienie tej relacji przedstawia się w istotnych dla wczesnego Feyerabenda, a klasycznych dla krytycznego racjonalizmu pracach.

Już w Logice odkrycia naukowego (1934) Karl Popper twierdził, że metoda, jaką proponuje, jest ,jedyną metodą wszelkiej racjonalnej dyskusji”" $\mathrm{W}$ konsekwencji tego oraz $\mathrm{w}$ duchu uznawanego przez siebie naturalizmu metodologicznego aplikował ją zarówno do interpretacyjnych zagadnień teorii kwantów, jak i do metodologii nauk społecznych. W Nędzy historycy$z m u$ (ogłoszonej w pierwszej wersji w 1936) Poppera kryterium demarkacji staje się podstawą rozróżnienia utopijnej i cząstkowej inżynierii społecznej. Pierwsza jest społecznym odpowiednikiem metafizycznych roszczeń poznawczych, druga - naukowych. Inżynieria utopijna wiąże się z podejściem holistycznym - jej „celem jest przebudowa »całego społeczeństwa« według z góry określonego planu"9 - i jest wyłącznie wytworem fantazji utopistów, „im głębsze bowiem mają być całościowe zmiany, tym większe będą ich niezamierzone i z reguły nieprzewidziane konsekwencje"10. Utopista będzie się posługiwał socjotechniką cząstkową, tyle że nieudolnie. Będzie odrzucał hipotezy mówiące o granicach instytucjonalnych działań. Holizm jest ogniwem przymierza między historycyzmem a utopizmem, oba są reakcją na doświadczenie zmiany, próbą jej racjonalizacji: historycysta absolutyzuje zaobserwowane trendy, wynosi je do roli nieuchronnych praw rozwoju społeczeństwa jako całości i prorokuje bieg tego rozwoju, utopista zaś domaga się nad tym rozwojem całkowitej kontroli lub jego powstrzymania. Historycyzm cechuje się deficytem poczucia perspektywy, absolutyzacją kategorii opisu zjawisk społecznych. Odrzucając różnorodność punktów widzenia, ich krytyczną dyskusję, odrzuca postęp wiedzy. W przeciwieństwie do jego historycyzmu cząstkowa socjotechnika uznaje, że wybór celów jest

${ }^{8}$ K.R. Popper: Logika odkrycia naukowego. Przeł. U. Niklas. Wyd. 2. Wydawnictwo Naukowe PWN, Warszawa 2002, s. 21.

${ }^{9}$ K.R. Popper: Nędza historycyzmu. Przeł. S. Amsterdamski. Wydawnictwo Naukowe PWN, Warszawa 1999, s. 73.

${ }^{10}$ Ibidem, s. 74. 
poza jej kompetencją; swoje zadanie widzi w ,projektowani[u] instytucji, doskonaleni[u] tych, które już istnieją" "11; kto zajmuje się socjotechniką cząstkową, ,nie wierzy w metodę całościowego przekształcenia społeczeństwa”"12, cele stara się „osiągnąc małymi krokami, stale przy tym korygując swoje posunięcia"13, unika reform, które uniemożliwiłyby mu odróżnienie przyczyn jego działań od ich skutków. Zgodnie z wymogami metody naukowej jest w stanie podać warunki, których zaistnienie oznaczałoby niepowodzenie jego programu. Tak według Poppera rozwijały się nauki społeczne. W dwóch tomach dzieła Społeczeństwo otwarte i jego wrogowie (1945) Popper prezentuje prostą typologię społeczeństw opartą na swoim kryterium. Twierdzi, że racjonalizm krytyczny sprzyja tytułowemu społeczeństwu otwartemu (jego powstaniu, utrzymaniu lub rozwojowi), do którego, począwszy od narodzin greckiej demokracji, dokonuje się przejście wszelkich społeczeństw. Jest to odwrót od społeczeństwa zamkniętego (plemiennego), które jednak czasem powraca $\mathrm{w}$ totalitaryzmach, cechujących się sztywnym i chronionym tabu, antyhumanitaryzmem, zwalczaniem ideologii egalitarystycznych, izolacją kulturową i gospodarczą. Obie formy społeczeństwa zamkniętego (plemienne i totalitarne) opierają się na myśleniu niepodatnym na krytyczną dyskusję, zindoktrynowanym, a ich socjotechnika jest utopijna. Już powstanie filozofii jako racjonalnego namysłu było, zdaniem Poppera, ,reakcją na upadek społeczeństwa zamkniętego i jego magicznych wierzeń" ${ }^{14}$. Obywatele społeczeństwa otwartego są autonomicznymi jednostkami, które mogą zakwestionować każdą instytucję i formę władzy, panuje wolność wypowiadania się i powszechna edukacja. Społeczeństwo to opiera się na wiedzy naukowej oraz socjotechnice cząstkowej, co nie oznacza wszak panowania specjalistów. Popper rozpowszechnił wśród swych wychowanków ${ }^{15}$ (uległ temu także Feyerabend we wczesnym okresie) niechęć do pewnych stanowisk teoretycznych - między innymi częściowo zgadzał się z ekonomizmem, natomiast z psychologizmem i socjologizmem już nie. Wskazywał na niemożność osiągnięcia założonego celu przez socjologię wiedzy (w jej ujęciu przez Karla Mannheima), który to cel rozumie Popper na swój sposób ${ }^{16}$. Według niego socjologia wiedzy miałaby być niejako przedłużeniem historycyzmu,

${ }^{11}$ Ibidem, s. 70.

12 Ibidem, s. 72.

13 Ibidem.

${ }^{14}$ K.R. Popper: Spoteczeństwo otwarte i jego wrogowie. T. 1: Urok Platona. Przeł. H. Krahelska. Oprac. A. Chmielewski. Wyd. 2. Wydawnictwo Naukowe PWN, Warszawa 1993, s. 211.

${ }^{15}$ I. Lakatos: Pisma z filozofii nauk empirycznych..., s. 338.

${ }^{16}$ K.R. Popper: Spoleczeństwo otwarte i jego wrogowie. T. 2: Wysoka fala proroctw. Hegel, Marks i nastepstwa. Przeł. H. Krahelska. Oprac. A. Chmielewski. Wydawnictwo Naukowe PWN, Warszawa 1993, s. 224-236. 
jest zatem niebywale niebezpieczna. Socjologów wiedzy Popper krytykuje za niedostrzeganie tego, że - choć „,czynniki społeczne” mają przemożny wpływ na rozwijających wiedzę naukową - racjonalność nauki zagwarantowana jest przez metodologię, intersubiektywność i wzajemną kontrolę w środowiskach uczonych ${ }^{17}$.

W wykładach wygłoszonych przez Feyerabenda w roku 1961, a opublikowanych jako Knowledge Without Foundations, widać wpływ Popperowsko-pozytywistycznej dychotomii: mianowicie przeciwstawione sobie zostają filozofia otwarta, czyli krytyczno-racjonalna, i zamknięta (dogmatyczna, odporna na krytycyzm). Pod wpływem swojego ówczesnego autorytetu Feyerabend jako niefalsyfikowalną formę myślenia wyróżnia mit - pozwala on wyjaśnić całość rzeczywistości i odnaleźć się w niej, codzienne doświadczenie zdaje się jego wyznawcom dobrze go potwierdzać, ściśle jednak zależy od tradycji, która go wytworzyła, funkcjonuje tylko w jej obrębie, jest niezrozumiały dla przedstawicieli innych kultur. Mit stanowi wynik indoktrynacji, której poddawani są członkowie społeczności, utrzymuje się dzięki temu, że odczuwają oni strach przed wykluczeniem. Podporządkowuje sobie formę życia grupy, ogranicza wyobraźnię młodych ludzi ${ }^{18}$. Z wypowiedzi Feyerabenda wynika, że cechy mitu można przypisać także niektórym teoriom naukowym oraz epistemologicznym i metodologicznym nurtom filozoficznym opartym na fundacjonali$z$ mie $^{19}$. Teoria czy system wiedzy staje się mitem nie tylko wtedy, gdy strukturalnie nie podlega falsyfikacji, lecz także wtedy, gdy podlega dogmatycznej akceptacji, jest broniony przez totalitarne instytucje. Remedium na taki stan rzeczy Feyerabend widzi w forsowanym przez Poppera wymogu otwartości na krytykę, jak również w uświadomieniu sobie, że żadna instytucja nie jest niczym więcej, jak tylko społecznym konstruktem, wobec czego wartości życiowe jednostki mają pierwszeństwo przed instytucjonalnymi ${ }^{20}$. Ostatnia z tych kwestii powraca w artykule Feyerabenda Jak być dobrym empirysta? (1963). Opisuje on sposoby działania „zamaskowanych obrońców nowej tyranii”21 głoszących demokratyczne hasła oraz zwolenników teorii i metodologii wykluczających teoretyczny pluralizm, dążących do utrzymania intelektualnego

17 Por. S. Hanuszewicz: Popper a socjologia wiedzy. W: Teoretyczne podstawy socjologii wiedzy. Red. P. Bytniewski, M. Chałubiński. T. 1. Wydawnictwo Uniwersytetu Marii Curie-Skłodowskiej, Lublin 2006, s. 198-210.

${ }^{18}$ D. Mączka: Mit i mity w filozofii Paula Feyerabenda. „Analiza i Egzystencja” 2017, nr 39, s. 97-116. https://doi.org/10.18276/aie.2017.39-06.

19 D. Mączka: Rola filozofii nauki w ujęciu Paula Feyerabenda. W: Episteme. O poznaniu filozoficznym i naukowym. Red. K. Bałękowski, P. Wiatr. Wydawnictwo Naukowe TYGIEL, Lublin 2016, s. 164-184.

${ }^{20}$ D. Mączka: Mit i mity $w$ filozofii Paula Feyerabenda...

${ }^{21}$ P.K. Feyerabend: Jak być dobrym empirysta?? W: Idem: Jak być dobrym empirystą? Przeł. K. Zamiara. Wydawnictwo Naukowe PWN, Warszawa 1979, s. 24. 
status quo, a ogłaszających się apologetami oświecenia (chodzi o atakowany przez Poppera empiryzm logiczny). „Ta metoda (świadomego, względnie nieświadomego) kamuflażu werbalnego - twierdzi Feyerabend - funkcjonuje na tyle dobrze, że zmyliła niektórych zagorzałych zwolenników prawdziwej demokracji. Mniej znany natomiast jest fakt, że współczesny empiryzm znajduje się dokładnie w tej samej, kłopotliwej sytuacji" ${ }^{22}$. Feyerabend pisze, że „[m]it nie ma więc obiektywnego związku z rzeczywistością, a przedłużenie jego istnienia jest wynikiem wysiłku społeczności wyznawców"23, choć rok wcześniej w tekście Wyjaśnianie, redukcja i empiryzm (1962) stwierdza także, iż „to, co się uważa w określonym czasie za »przyrodę«, jest naszym własnym wytworem" ${ }^{24}$. Widać więc, że wbrew temu, co filozof deklaruje w pracy Realizm $i$ instrumentalizm, jego stanowisko w kwestii realizmu naukowego jest dalekie od jednoznaczności ${ }^{25}$. Już w 1962 roku zwraca uwagę na różnego typu uwarunkowania pracy badawczej; są to: indywidualne przyzwyczajenia badacza, przekonania i uprzedzenia swoiste dla danej tradycji badawczej, przeświadczenia metafizyczne, jakie towarzyszą danemu pokoleniu, oraz struktura języka, jakim się ono posługuje. Inny przebieg praktyki naukowej niż oczekiwany przez metodologię nie stanowi dla Feyerabenda większego problemu, podobnie jak Popper broni on natomiast normatywnego charakteru metodologii, która (o ile jest pluralistyczna) pozwala znieść „,[p]araliżujący wpływ tego, co dobrze znane"26. Filozof nie wychodzi zatem poza poglądy Poppera na relację wiedzy naukowej i czynników „pozaracjonalnych”, co widać znów przy okazji krytyki supremacji starszych teorii. Pisze, że okoliczność wcześniejszego pojawienia się teorii ,stanowi uboczny czynnik o charakterze psychologicznym i historycznym, w związku z czym nie powinna mieć żadnego wpływu na kwestie interpretacji i rzeczywistości”27.

\section{Przejście do okresu radykalnego}

Zasadnicza zmiana, jaka dokonuje się w filozofii Feyerabenda, widoczna jest wyraźnie już w jego artykule Ku pocieszeniu specjalisty

${ }^{22}$ Ibidem.

${ }^{23}$ Ibidem, s. 47.

${ }^{24}$ P.K. Feyerabend: Wyjaśnianie, redukcja i empiryzm. W: Idem: Jak być dobrym empirysta?..., s. 63.

${ }_{25}$ P.K. Feyerabend: Realizm i instrumentalizm. W: Idem: Jak być dobrym empirysta?..., S. 181.

${ }^{26}$ Ibidem, s. 108.

27 Ibidem, s. 122. 
(1970), przy okazji polemiki z Thomasem Kuhnem, z którym dyskusje prowadził, odkąd w 1960 roku zapoznał się z rękopisem Struktury rewolucji naukowych. W koncepcji Kuhna Feyerabend zauważa dwuznaczność. Jeśli koncepcja ta miałaby być wyłącznie opisowa, pojawiają nad wyraz kłopotliwe implikacje: „Każde stwierdzenie Kuhna dotyczące normalnej nauki pozostaje prawdziwe po zastąpieniu terminu »normalna nauka« terminem »zorganizowane przestępstwo «"28. Jeśli miałaby być normatywna, to - zdaniem Feyerabenda - staje się wyrazem elitaryzmu (to także zarzut Lakatosa ${ }^{29}$ ). Feyerabend jednak inaczej postrzega funkcjonowanie nauki. Paradygmaty są przezwyciężane nieustannie, ,składnik normalny” i „składnik filozoficzny” (ekwiwalenty okresów „nauki normalnej” i „rewolucji naukowej”) współdziałają: „Inwencja taka ma miejsce cały czas. Pomimo tego, tylko podczas rewolucji skierowana jest na nią uwaga. Ta zmienność uwagi nie jest [...] niczym innym jak zmianą zainteresowań i publiczności" 30 . Rewolucje są odczuwalne jedynie periodycznie, ponieważ ów „składnik normalny” (choć sam z siebie dominujący) zostaje osłabiony na skutek zmian społecznych, prowadzących (co jakiś czas) do wzmocnienia wpływu „czynnika filozoficznego”: „Opiera się on bowiem silnie wszelkim zmianom. Opór ten [jest - J.L.] [...] ukierunkowany przeciwko składnikowi filozoficznemu, powodując uświadomienie sobie tego ostatniego przez ogół. Młodsza generacja, zawsze żądna nowości, korzysta z owego materiału, gorliwie go studiując. Publicyści, baczący zawsze na nagłówki w prasie - im bardziej absurdalne, tym lepsze - publikują nowe odkrycia (są nimi elementy składnika filozoficznego)" ${ }^{31}$. Feyerabend twierdzi, że Kuhn daremnie poszukuje wewnętrznej „logiki przemian historycznych". Przyczyną zmiany „składnika normalnego" może być szereg prozaicznych okoliczności, przykładowo to, że „nie można zadręczać młodszego pokolenia obowiązkiem słuchania starszych, względnie fakt, iż pewna znana osobistość zmieniła osobowość lub jakiś wpływowy przedstawiciel panującego w nauce kierunku zmarł" 32 . Dalej pojawiają się antycypacje twierdzeń z okresu radykalnego. Twierdzi, że w nauce, jak w życiu społecznym, zwolennicy danego stanowiska napotykający na brak warunków sprzyjających przyjęciu się ich argumentacji, muszą stosować się do środków pozaracjonalnych, jak propaganda. Pisze, że naukę „niełatwo oddzielić [...] od całokształtu procesu dziejowego, że zawsze wyko-

${ }^{28}$ P.K. Feyerabend: Ku pocieszeniu specjalisty. W: Idem: Jak być dobrym empirysta?..., s. 203.

${ }^{29}$ I. Lakatos: Pisma z filozofii nauk empirycznych..., s. 345.

${ }^{30}$ P.K. Feyerabend: Ku pocieszeniu specjalisty..., s. 214.

${ }^{31}$ Ibidem, s. 220.

32 Ibidem, s. 221. 
rzystywała ona i wykorzystuje każdy talent i każde szaleństwo ludzkie"33, co uwidacznia znaczenie czynników indywidualnych. Ze względu na złożoność tego zjawiska, aby zbadać naukę w pełni, musimy uwzględnić „przypadek, przesądy, warunki materialne (takie jak istnienie określonego typu szkła w jednym, a nie w innym kraju)", a nawet, choć bez przesadnej uwagi, „nietrwałość pożycia małżeńskiego, przeoczenie, pobieżne traktowanie spraw, próżność i wiele innych rzeczy"34. Idea tak szczegółowego badania praktyki naukowej podjęta została kilka lat później równolegle przez Brunona Latoura, Steve'a Woolgara ${ }^{35}$ i Karin Knorr-Cetinę w rozwijającym się od tamtego czasu nurcie etnografii laboratorium ${ }^{36}$.

\section{Okres radykalny}

\section{Wpływ Whorfa i późnego Wittgensteina}

Obraz funkcjonowania wiedzy i jej szczególnej formy, leżącej w centrum zainteresowania Feyerabenda, czyli nauki, najpełniej ,przedstawiony” został w pracy Przeciw metodzie (1975). Rekonstrukcja tego obrazu jest niełatwa, gdyż dzieło stanowi raczej polemiczny kolaż niż wykład idei. Uderzające jest, że różne formy wiedzy, występujące w społeczeństwach na przestrzeni wieków, Feyerabend nazywa ideologiami. By wyjaśnić, czemu służy taki werbalny zabieg (sam Feyerabend tego nie tłumaczy), konieczne będzie odwołanie się do niektórych koncepcji późnego Ludwiga Wittgensteina i Benjamina L. Whorfa, na których Feyerabend się powołuje, gdyż właśnie ich wpływ jest tu szczególnie istotny.

Wpływ filozofii późnego Wittgensteina na Feyerabenda jest bardziej złożony niż wynikałoby to z uwag tego drugiego, stosownie więc będzie omówić wspólne elementy ich zapatrywań na relację wiedzy i kultury. Poglądy

${ }^{33}$ Ibidem, s. 222.

34 Ibidem, s. 224.

35 Por. B. Latour, S. Woolgar: Życie laboratoryjne: konstruowanie faktow naukowych. Tłum. K. Abriszewski. Narodowe Centrum Kultury, Warszawa 2020.

${ }^{36}$ Por. K. Knorr-Cetina: Etnograficzne studium pracy naukowej: w stronę konstruktywistycznej interpretacji nauki. W: Studia nad nauka i technologia. Wybór tekstów. Red. E. Bińczyk, A. Derra. Tłum. M. Wróblewski. Wydawnictwo Naukowe Uniwersytetu Mikołaja Kopernika, Torun 2014, s. 181-215. 
przedstawione w Dociekaniach filozoficznych poznał Feyerabend przez apologetkę i przyjaciółkę Wittgensteina - filozofkę Elizabeth Anscombe (o rozmowach z nią pisze: „Wywarły na mnie głęboki wpływ, chociaż bynajmniej niełatwo podać szczegóły" ${ }^{\prime 37}$ ), samego filozofa zaś spotkał tylko raz. Momenty owego wpływu wymieniane w literaturze to:

1. Kontekstualna teoria znaczenia, związana $\mathrm{z}$ tezą o niewspółmierności interteoretycznej ${ }^{38}$.

2. Gramatyka zwrotów widzieć, że, widzieć jako. Wojciech Sady w Wittgenstein. Życie i dzieło pisze: „Idea, że ten sam obraz opisywać można na różne sposoby - i w pewnym sensie różnie go widzieć - oddziałała silnie na S.E. Toulmina i P.K. Feyerabenda" ${ }^{\prime 3}$.

3. Niewystarczalność racji. W książce Spór o racjonalność naukowa Sady przytacza słowa z $O$ pewności: „U kresu racji stoi perswazja”, i dodaje, że „Feyerabend za autorem Dociekań filozoficznych podkreśla, że nie ma innego sposobu przekonania oponentów"40. Przekonaniu o niewystarczalności racji w praktyce językowej Wittgenstein daje wyraz już w Dociekaniach filozoficznych: „Jeżeli znaczy to: „Czy mam jakieś racje?«, to odpowiedź brzmi: racje rychło mi się skończą. I wtedy działać będę bez racji”^1 . Należy to jednak rozumieć nie jako pochwałę „irracjonalizmu”, ale jako podkreślenie pierwszeństwa praktyki, sytuacji kulturowej, czyli istnienia (użyję frazy Georga Henrika von Wrighta) „zakończeń łańcuchów racji” - kresów dowodzenia zakorzenionych w sposobach życia ${ }^{42}$. Z jednej strony perswazja jest jednym $\mathrm{z}$ elementów partycypowania w kulturze, negować jej wpływu niepodobna. $Z$ drugiej strony na „obraz świata” składają się elementy jednocześnie „pozaracjonalne” i niewyperswadowane: „Mojego obrazu świata nie mam jednak dlatego, że przekonałem się o jego słuszności; ani dlatego, że zostałem przekonany o jego słuszności. Lecz jest to odziedziczone tło, na którym odróżniam prawdę od fałszu”43 - pisze Wittgenstein w $O$ pewności.

Poza wymienionymi w literaturze ideami Wittgensteina, które wpłynęły na Feyerabenda, należy wskazać jeszcze:

37 P.K. Feyerabend: Przeciw metodzie. Przeł. S. Wiertlewski. Red. nauk. przekładu K. Zamiara. Siedmioróg, Wrocław 2001, s. 258.

${ }^{38}$ K. Jodkowski: Filozofia nauki Paula K. Feyerabenda. Stadium umiarkowane. „Studia Filozoficzne" 1979, nr 11, s. 65.

39 W. Sady: Wittgenstein. Życie i dzieło. Daimonion, Lublin 1993, s. 117.

${ }^{40}$ W. Sady: Spór o racjonalność naukowa..., s. 371.

${ }^{41}$ L. Wittgenstein: Dociekania filozoficzne. Przeł. B. Wolniewicz. Wydawnictwo Naukowe PWN, Warszawa 2000, s. 123.

${ }^{42}$ L. Wittgenstein: O pewności. Przeł. B. Chwedeńczuk. Wydawnictwo KR, Warszawa 2001, s. 121.

43 Ibidem, s. 23. 
1. Dostrzeganie złożoności i wielości; w filozofii Wittgensteina dotyczyło to gier językowych, sposobów życia, a także „obrazów świata”. Już w Uwagach o „Ztotej Gatęzi” Frazera widać odrzucenie ujednolicających różnorodne „sposoby życia” perspektyw, charakterystycznych dla niektórych zachodnich badaczy (racjonalistów - w nomenklaturze Feyerabenda): „Jakże ograniczone jest życie duchowe według Frazera! A w następstwie: jakaż nieumiejętność rozumienia życia innego niż życie we współczesnej mu Anglii!"’44. Niezadowalające jest według Wittgensteina na przykład ocenianie magii jako formy nauki, a wszelkiego działania tradycyjnych ludów jako działania na podstawie „poglądów”. Feyerabend natomiast podkreśla wielość rodzajów wiedzy, tradycji, nauk. Gdy Wittgenstein wskazuje na bezzasadność sprowadzania języka do choćby zdań oznajmujących i na wielość tworów językowych, a nawet użyć tego samego słowa $\mathrm{w}$ różnych okolicznościach (przekornie przedstawia w Dociekaniach filozoficznych języki, w których zdań oznajmujących nie ma wcale, języki te służą jedynie koordynacji społecznej praktyki), Feyerabend analogicznie odnosi się do szeroko rozumianych systemów wiedzy - równie przekornie wskazuje na alternatywne dla zachodnich kosmologie. W dodatku obaj czynią to w opozycji do swoich wcześniejszych poglądów. Można rzec, iż obaj dokonują pluralistycznego zwrotu. Jednocześnie Wittgenstein daleki jest od stawiania tezy o niewspółmierności „obrazów świata”, co stanowi wartą podkreślenia różnicę między myślicielami, jeśli chodzi o konsekwencje wyciągane ze wspomianego pluralizmu. Wittgenstein pisze bowiem: „Nonsensem jest to, że Frazer przedstawia rzeczy tak, jak gdyby ludy te miały całkowicie fałszywe (nawet obłędne) wyobrażenie o biegu przyrody, podczas gdy posiadają jedynie szczególną interpretację zjawisk. To znaczy, ich wiedza o przyrodzie, jeśliby ją spisali, nie różniłaby się od naszej w sposób fundamentalny. Jedynie ich magia jest inna" ${ }^{\text {"45. }}$. Feyerabend zaś przyjmuje ową tezę - nie wierzy, by na gruncie własnej teorii dało się $\mathrm{w}$ pełni zrozumieć obcą. Twierdzi, że nawet w odniesieniu do nowych teorii fizycznych niezbędne jest postępowanie antropologiczne - przyswojenie obcego języka, wyjście poza swoją teorię, dopuszczenie myślenia absurdalnego z jej punktu widzenia, by ten punkt zmienićc ${ }^{46}$.

2. Uwydatnienie roli tresury i czynników pozaargumentacyjnych w przyswajaniu wiedzy, kształtowaniu pokoleń (co wiąże się z opisanym wcześniej „kresem racji”). Według Wittgensteina uczenie się gier językowych dokonuje się nie na drodze objaśnień, ale naśladownictwa, czy ogólnie -

${ }^{44}$ L. Wittgenstein: Uwagi o „Złotej Gałęzi” Frazera. Przeł. A. Orzechowski. Instytut

Kultury, Warszawa 1998, s. 16.

${ }^{45}$ Ibidem, s. 31.

${ }^{46}$ P.K. Feyerabend: Przeciw metodzie..., s. 186. 
działania. Feyerabend zdaje się opisywać zastosowanie tej koncepcji do postępowania uczonych na podstawie obowiązującej teorii (Kuhn pisze o szkoleniu następców w paradygmacie) i podkreśla, że „tam, gdzie argumentacja zdaje się wywierać wpływ, wynika to częściej z faktu wielokrotnego jej wygłaszania niż z jej semantycznej treści" ${ }^{\prime 4}$.

$\mathrm{Na}$ koniec należy uwidocznić kwestię, na którą zwraca uwagę Aleksandra Derra. Choć tak istotne pojęcia Dociekań filozoficznych, jak sposób życia i praktyka, ściśle wiążą się z określonym otoczeniem kulturowym, nie redukują się do czysto społecznych konstruktów, z tych samych względów, $\mathrm{z}$ jakich nie redukują się do żadnego innego jednego źródła. Wynika to z odrzucenia przez późnego Wittgensteina dwuaspektowej teorii znaczenia ${ }^{48}$.

Wojciech Sady pisze: „Osobiście uważam, że późnego Wittgensteina powinno się czytać przez pryzmat doktryny relatywizmu językowego"49. Słowa te skłaniają do uwzględnienia łącznego wpływu Wittgensteina i Whorfa na filozofię Feyerabenda.

Benjamin L. Whorf w słynnych artykułach z lat 1940-1941 zwięźle wyraził idee, które zostały podjęte i zaprezentowane w nieładzie w Przeciw metodzie Feyerabenda. Warto przedstawić kilka z nich. Wszelka wiedza wyrażana jest $\mathrm{w}$ języku, podlega prawom gramatyki, „która jest niczym innym jak tylko zbiorem norm poprawności społecznej i konwencjonalnej" ${ }^{\prime 50}$. Zaplecze językowe współtworzy wyrażane idee, klasyfikuje rzeczywistość, konstytuuje obraz świata przyjmowany przez społeczność, co według Whorfa może być niewidoczne, póki pozostaje się w obrębie (podobnych pod względem wzorca) łaciny, greki i języków europejskich, a także „,w każdym spójnym żargonie specjalistycznym"s1. Zjawisko to wspiera działanie tego, co Whorf nazywa „logiką naturalną” (,zdrowy rozsądek”, realizm naiwny). W tekście Językoznawstwo a nauka Whorf pisze: „Nie doznawszy niczego, co byłoby z taką »regułąu niezgodne, nie jesteśmy w stanie wyodrębnić jej i sformułować" 52 , dlatego zasadnicze różnice w postrzeganiu świata ujawniają się dopiero w kontakcie z inną kulturą: ,postrzegający nie utworzą sobie tego samego obrazu świata na podstawie tych samych faktów fizycznych, jeśli ich zaplecza językowe nie są podobne lub przynajmniej porównywalne" 53 .

${ }^{47}$ Ibidem, s. 24.

48 A. Derra: Specyficzny kontekst społeczny i jego rola $w$ teorii znaczenia późnego Wittgensteina. „Kognitywistyka i Media w Edukacji” 2007, nr 1/2, s. 133-141.

${ }^{49}$ W. Sady: Wittgenstein..., s. 127.

${ }^{50}$ B.L. Whorf: Nauka a językoznawstwo. W: Idem: Język, myśl i rzeczywistość. Przeł. T. Hołówka. Wydawnictwo KR, Warszawa 2002, s. 280.

${ }^{51}$ Ibidem, s. 330.

${ }^{52}$ Ibidem s. 281.

${ }^{53}$ Ibidem, s. 286. 
Istnieją więc zupełnie odmienne systemy wiedzy, w których ,[t]ak szacowne kategorie kultury Zachodu, jak czas, materia, prędkość, okazują się nie mieć aż tak doniosłego znaczenia dla konstruowania spójnego obrazu rzeczywistości”'54. W tekście Językoznawstwo jako nauka ścisła Whorf sformułował to, co najistotniejsze dla filozofii okresu radykalnego Feyerabenda: „Z każdego takiego naiwnego i niesformułowanego poglądu na świat może wyrosnąć pogląd naukowy, dany explicite" ${ }^{\text {"55 }}$.

Konstatacja amerykańskiego językoznawcy dotycząca postawy, jaką w jego czasach przyjęła kultura Zachodu wobec tej różnorodności, jest zbieżna z wnioskiem Feyerabenda: kultura ta dokonała „za pośrednictwem języka pewnej doraźnej analizy rzeczywistości i nie dopuszczając myśli o korekcie, utrzymuje, iż jest to analiza ostateczna" ${ }^{95}$. W tekście Język, umyst i rzeczywistość Whorf wskazuje na to, co można uznać za kamień węgielny anarchizmu metodologicznego i co Feyerabend uważa za rzeczywistą część praktyki naukowej, ujawniającą się w historii nauki: „obcość przeradza się w nowy i przenikliwy sposób patrzenia na rzeczy"57 - nauka rozwija się, bo społeczności uczonych przyswajają ową „obcość”. Koncepcje te Feyerabend aplikuje do rozważań nad teoriami fizycznymi. Stosując pojęcie ukrytych klasyfikacji, tworzących nawykowe opory wobec odmiennych ujęć, zawartych w gramatykach języków (a więc w wyznaczonych przez nie kosmologiach), opisuje, jak: „,[d]yskusje przygotowujące przejście do nowej epoki w fizyce lub astronomii rzadko kiedy dotyczą wyłącznie jawnych rysów ortodoksyjnego punktu widzenia. Często ujawniają one ukryte idee, zastępują je ideami odmiennego rodzaju i zmieniają tak jawne, jak i ukryte klasyfikacje"s8.

\section{Funkcjonowanie systemów wiedzy}

Na podstawie poczynionych rozważań wywnioskować można, dlaczego różne formy wiedzy (praktyki, kultury) występujące w społeczeństwach, nazywa Feyerabend ideologiami. Te szeroko rozumiane teorie przyswajane są na drodze tresury, opierają się na niejawnym zapleczu językowym, brane są za samooczywiste, ignorują swoje historyczne podłoże, wytwarzają iner-

${ }^{54}$ Ibidem, s. 291.

55 B.L. Whorf: Językoznawstwo jako nauka ścisła. W: Idem: Język, myśl i rzeczywistośćc..., s. 297.

${ }^{56}$ B.L. Whorf: Języki i logika. W: Idem: Język, myśl i rzeczywistość..., s. 328.

${ }^{57}$ B.L. Whorf: Język, umyst i rzeczywistość. W: Idem: Język, myśl i rzeczywistość..., s. 353.

${ }^{58}$ P.K. Feyerabend: Przeciw metodzie..., s. 167. 
cyjny opór wobec odmiennych praktyk - z tych powodów mają tendencję do lekceważenia siebie nawzajem i zabiegania o monopol w sferze publicznej. Nazywanie ich przez Feyerabenda ideologiami nie ma waloru analitycznego, a wyłącznie emocjonalny (filozof korzysta z potocznych konotacji tego słowa, jego retorycznej siły) i służy wskazaniu pewnych cech wszelkiej wiedzy. Mogą być religijne, naukowe, artystyczne, polityczne, ale mają paralelne sposoby funkcjonowania i wykazują dwie ogólne tendencje: $\mathrm{z}$ jednej strony do separacji, z drugiej do interakcji. Pisał Feyerabend: „Indianie znali i nadal znają wiele »faktów « dotyczących ludzi, zwierząt, roślin i ich naturalnego współdziałania, które w najmniejszym stopniu nie interesują biologa molekularnego [...]. Donald Johanson, podróżnik z »Lucy«, znał fakty dotyczące formacji geologicznych, szkieletów świn, anatomii małp i ludzi, nie wywarło to jednak najmniejszego wrażenia na Afarach, którzy pomagali jego ekspedycji” ‘99. Poszczególne tradycje wytwarzają swoje kosmologie pod wpływem po części przypadku, po części doświadczenia oporu rzeczywistości, po części potrzeb i oczekiwań towarzyszących przezwyciężaniu przeszkód ${ }^{60}$. Kosmologie te są „kształtowane z materiału, który w zależności od sposobu potraktowania wytwarza bogów, duchy i naturę będącą raczej partnerem ludzi niż laboratorium dla ich eksperymentów lub też wytwarza kwarki, pola, molekuły, płyty tektoniczne" ${ }^{\text {. }}$. Normy racjonalności i argumenty na ich rzecz są ,„zewnętrzną stroną《 określonych tradycji składających się z jasnych, explicite danych zasad oraz $\mathrm{z}$ niedostrzeganego, w znacznym stopniu nieznanego, lecz absolutnie koniecznego zaplecza w postaci dyspozycji umożliwiających działanie i sądzenie" ${ }^{\prime 2}$. Mają też odmienne sposoby zdobywania zwolenników/zwolenniczek - ten sam argument będzie dla jednej osoby propagandą, dla drugiej - istotą dyskursu. Feyerabend zwraca uwagę na różnego rodzaju zjawiska deprecjacji obcej formy wiedzy; na przykład, gdy ktoś próbuje się sprzeciwiać dominującej ideologii, zmuszany jest, by wyartykułować tę krytykę $\mathrm{w}$ jej terminach, co z góry skazuje ją na niepowodzenie. Przytacza za Johnem Stuartem Millem ogólny schemat „stopniowego przekształcania idei rewolucyjnych $\mathrm{w}$ przeszkody w myśleniu" ${ }^{63} \mathrm{w}$ instytucjach nauki: Przyjęcie się nowego poglądu napotyka na poważne trudności, przytaczane racje są machinalnie lekceważone. Dopiero kolejne pokolenie jest bardziej dociekliwe, prowadzi niestandardowe badania, ich niespodziewane wyniki z trudem wprowadzają ów pogląd w obręb dyskusji. Dawni przeciwnicy „czują się zobligowani do przestudiowania jednego lub drugiego artykułu, wygłoszenia

\footnotetext{
59 Ibidem, s. 240

${ }^{60}$ Ibidem, s. 248

${ }^{61}$ Ibidem, s. 242.

${ }^{62}$ Ibidem, s. 227.

${ }^{63}$ Ibidem, s. 37.
} 
kilku sarkastycznych komentarzy”64, a następnie owa teoria „przestaje być ezoterycznym tematem dyskusji na zaawansowanych seminariach i konferencjach, stając się domeną publiczną"65. Pojawiają się pierwsze opracowania i wprowadzenia, teoria zdobywa kolejnych zwolenników/zwolenniczki, z których część kieruje się prozaicznym konformizmem, ,pragnienie bycia po słusznej stronie jest brane jako kolejny znak świadczący o ważności tej teorii' ${ }^{\prime 6}$. Nie znaczy to, że owa teoria faktycznie zostaje lepiej zrozumiana. W końcu jej problematyczne aspekty zaczynają być chronione przed podważeniem, „zamieniają się w slogany" i schemat się powtarza ${ }^{67}$.

Separacja nie trwa jednak długo, ideologie wchodzą z sobą w interakcje, gdyż „nie ma takiej tradycji, niezależnie od interesowności jej uczonych czy ciężkiej ręki jej wojowników, która nie ulegałaby wpływom tego, co dzieje się wokół niej" ${ }^{68}$. Interakcje zależą od typów uczestniczących w nich ideologii (naukowe, religijne, artystyczne, polityczne itd.), warunków historycznych, lecz zawsze praktyki uczestniczące ulegają przemianom (przezwyciężanie jednych, autonomizowanie się drugich, powstawanie nowych). Towarzyszą temu jawne lub niejawne zmiany w świadomości uczestników/uczestniczek, mogą oni/one nieraz doświadczyć, że oto „pojawiła się idea jakiejś »Ameryki wiedzy«, całkowicie nowego i jeszcze nie przeczuwanego kontynentu wiedzy, który można odkryć, tak jak odkryto rzeczywistą Amerykę" ${ }^{96}$. Oto dwa przykłady przytaczanych przez Feyerabenda interakcji różnych praktyk:

1. Związek powstania nowożytnej nauki $\mathrm{z}$ całym ruchem społecznym. Galileusz przedstawiony przez Feyerabenda nie stroni od propagandy i chwytów psychologicznych w obronie swych przekonań (o niektórych słabościach tego opisu kampanii Galileusza pisze Anna Michalska ${ }^{70}$ ), pojawia się nowa klasa ,profanów, posiadających nowy obraz świata i pogardzających nauką uprawianą w szkołach, jej metodami, wynikami, a nawet językiem"'71. Rodząca się nauka nowożytna otwiera przed tymi ludźmi nową, porywającą wizję świata, sama zaś zyskuje, gdyż jest dzięki temu upowszechniana.

${ }^{64}$ Ibidem.

${ }^{65}$ Ibidem.

${ }^{66}$ Ibidem.

${ }^{67}$ Ibidem.

${ }^{68}$ Ibidem, s. 227.

${ }^{69}$ Ibidem, s. 220.

70 A. Michalska: Nauka - dyskurs czy propaganda? Kampania Galileusza w świetle anarchizmu Paula Feyerabenda oraz koncepcji dziatania komunikacyjnego Jurgena Habermasa. „Argument” 2012, nr 2, s. 377-396. Pobrano z: https://argument.up.krakow.pl/ article/download/6353/5881/ [23.11.2021].

${ }^{71}$ P.K. Feyerabend: Przeciw metodzie..., s. 118. 
2. Interakcja zachodniej medycyny z siłami politycznymi Chin. Nowe pokolenie odrzuca jako relikty przeszłości zdobycze wielowiekowej tradycji na rzecz współczesnej medycyny. Następnie władze partyjne uznają odkrycia nauki zachodniej za „burżuazyjne” i wprowadzają kampanię na rzecz odrodzenia dawnych praktyk. Według Feyerabenda w następstwie wykrywane są zarówno słabe, jak i wartościowe strony obu ideologii, które nie zostałyby wykryte, gdyby nie doszło do interakcji. Uczestnicząc $\mathrm{w}$ danej praktyce, nie mamy pełnej kontroli nad jej elementami, ulegają one zmianom, „chociaż pragniemy je ustabilizować, a opierają się zmianom tam, gdzie chcielibyśmy wprowadzić nieco więcej elastyczności. Możliwości zmiany dają o sobie znać w strukturze języków, zawodów, form sztuki" 72 . Rozwojowi ideologii miałyby sprzyjać na przykład: krytyka z przeszłości ${ }^{73}$ (zjawisko rewidowania stanu wiedzy - wywołane tym, że członkowie/członkinie danej tradycji zwracają się do swych źródeł lub innej dawnej tradycji) oraz stosowanie propagandy (,służy wywołaniu zainteresowania” i jego podtrzymaniu, ,aż nie pojawią się nowe racje”) ${ }^{74}$.

\section{Racjonaliści, pragmatycy, współczesna nauka}

Zrekonstruowane na podstawie rozważań Feyerabenda dwa typy idealne grup występujących w danej tradycji można powiązać z dwoma wymienionymi przez filozofa sposobami kolektywnego rozwiązywania problemów:

1. Racjonaliści. W realiach współczesnej nauki do grupy tej Feyerabend zalicza większość filozofów/filozofek nauki, część naukowców/naukowczyń, jak również siebie z okresu umiarkowanego. Jednakże inne praktyki też mogą mieć taką grupę, o czym świadczą choćby porównania „dzisiejszych racjonalistów” z „ekspertami kościelnymi”, którzy włączyli się w proces Galileusza $^{75}$. Racjonaliści są przekonani o istnieniu obiektywnych wymogów, które spełnić powinna każda tradycja, Feyerabend przedstawia ich jako konformistów, którzy aby utwierdzić się w swoich przekonaniach, potrzebują instytucjonalnej aprobaty, w swoich kręgach są niemal jednomyślni, jako jednostki oceniają swoje i cudze życie w kategoriach akademickich ${ }^{76}$, są odruchowo oporni wobec ideologii, w których nie zostali przeszkoleni

\footnotetext{
72 Ibidem, s. 242.

73 Ibidem, s. 43.

74 Ibidem, s. 120.

75 Ibidem, s. 134.

76 Ibidem, s. 154.
} 
w karierze zawodowej lub które są lekceważone w ich środowiskach ${ }^{77}$. Feyerabend twierdzi, że „szarlatani”, których wpływu obawiają się racjonaliści, uzyskują go dlatego, że życie publiczne jest zdominowane właśnie przez racjonalistów. Człowiek należący do takiej grupy jest „niezdolny do zdania sobie sprawy z tego, że to, co uważa za »głos rozsądku«, jest jedynie następstwem przyczynowym wykształcenia, jakie otrzymał [...], nie jest niczym innym jak pociągnięciem politycznym" ${ }^{78}$. W grupach tych obowiązuje typ debaty nazywany przez Feyerabenda kierowanym i polegający na tym, że wszyscy uczestnicy/wszystkie uczestniczki przyjmują ściśle określoną tradycję, a jeśli ktoś takowej nie przyjmuje, pozostaje tak długo pod wpływem presji i przekonywań, aż się dostosuje. Dopiero wtedy zaczyna się (jednomyślna) dyskusja.

2. Interakcjoniści (pragmatycy). To, co racjonaliści uważają za „rozum”, jest dla interakcjonistów jedną z praktyk, które rozpatrywane są we wzajemnym oddziaływaniu. Żadna praktyka nie jest przez nich przyjmowana jako ostateczny, niewzruszony punkt odniesienia. Feyerabend zauważa jednak, że niewiele grup może być pragmatykami, gdyż „trudno jest spojrzeć z zewnątrz na poglądy, do których jest się najbardziej przywiązanym, jako na część zmieniającej się i być może absurdalnej tradycji" interakcjonistów wykorzystywana jest debata otwarta, w której określona praktyka czy tradycja rodzi się dopiero podczas wymiany, partycypujący/partycypujące „włączają się w cudze sposoby myślenia, odczuwania, percepowania [...]. [Ich - J.L.] poglądy na świat ulegają radykalnym zmianom" $"$. Wymiana otwarta nie zakłada żadnej szczególnej metodologii, dopiero w trakcie debaty metodologia może się wytworzyć. Można powiedzieć, że to uogólnienie lansowanego przez Feyerabenda ,postępowania kontrindukcyjnego" w nauce na dowolny układ między ideologiami.

Nauka jest więc jedną z praktyk, jej kosmologia to ,[b]yt dynamiczny, o wielu twarzach, oddziałujący na badaczy, a zarazem odzwierciedlający ich działalność oraz ciągle zmieniające się systemy społeczne, które ich otaczają" ${ }^{21}$. Uczeni to „rzeźbiarze” rzeczywistości, wytwarzają nie tylko systemy fizyczne, lecz także semantyczne warunki prowadzące do „przekonywających wnioskowań - ze znanych efektów o nowych i zadziwiających projekcjach" " 2 . Feyerabend nazywa naukę „przedsięwzięciem anarchistycznym", gdyż mimo wpływu racjonalistów historycznie zawsze dochodziło

\footnotetext{
${ }^{77}$ Ibidem, s. 235.

78 Ibidem, s. 25.

79 Ibidem, s. 221.

${ }^{80}$ Ibidem, s. 229.

81 Ibidem, s. 248.

${ }^{82}$ Ibidem, s. 249.
} 
do interakcji między teoriami naukowymi a innymi teoriami, kulturami czy ideologiami, funkcjonowały też grupy pragmatyków, którzy nie stosowali się do obowiązujących norm. A jednak, w przekonaniu Feyerabenda, rzeczywisty wpływ nauki na współczesne społeczeństwo stał się zgubny. Filozofa koncepcja przyszłego free society opiera się na takich właśnie przekonaniach. Choć przedstawienie samej wizji przekracza ramy niniejszego artykułu, tkwiące u jej podstaw założenia ze względu na ich opisowy charakter zostaną jeszcze pokrótce omówione.

U zarania nowożytnej nauki wiązała się ona ze zwalczaniem autorytaryzmu i przesądów, współcześnie jednak łączy się z pewnymi mitami, które kontrastują z demokratycznym nastawieniem Zachodu. Feyerabend twierdzi, że fakty naukowe są wpajane młodym ludziom w procesie edukacji dokładnie tak jak niegdyś dogmaty religijne, a w środowiskach naukowych silny wpływ wywiera wykluczenie przywołujące na myśl instytucję herezji ${ }^{83}$. Usprawiedliwia się to mitem, że za współczesną nauką stoi niezawodna metodologia, tyle że (w przekonaniu Feyerabenda) takiej nie ma. Kolejny mit głosi, że nauka swoje wyniki uzyskuje samodzielnie. W luźnym wykładzie Jak obronić społeczeństwo przed nauką? Feyerabend pisze, że prawie nigdy tak nie jest, a nawet, że ,[m]echanika, optyka zawdzięczają wiele rzemieślnikom, medycyna akuszerkom i czarownicom. W obecnych zaś czasach widzimy, jak ingerencja państwa może doprowadzić do rozwoju nauki”" ${ }^{\prime 4}$. Warto zważyć, na jak zaskakująco naiwnej wizji „polityki” opiera się Feyerabend, między innymi wtedy, gdy twierdzi, że „dzisiejsze państwo” jest „całkowicie neutralne ideologicznie" ${ }^{55}$. W popularyzującym artykule Mit ,nauki” $i$ jego rola $w$ społeczeństwie pisze, że $\mathrm{w}$ przedsięwzięciach naukowych istnieje „,szeroki zakres swobody pozwalającej stosować metody tajnego, demokratycznego głosowania - swobody, którą jednak w chwili obecnej ogranicza polityka siły oraz propaganda" ${ }^{96}$. Z kolei mit immanentnego elitaryzmu nauki Feyerabend zbywa, zrzucając jej ekskluzywizm na karb niewłaściwej edukacji. Dominacja nauki miałaby zagrażać różnorodności tradycji i praktyk, a wspierana jest dużymi nakładami finansowymi, natomiast „,w]zględy humanitarne sprowadzono do minimum" ${ }^{87}$. Ten niepokojący obraz należałoby skonfrontować z badaniami empirycznymi, wielu tez Feyerabenda nie daje

${ }^{83}$ P.K. Feyerabend: Jak obronić społeczeństwo przed nauka? W: Czy sprzeczność może być racjonalna. Red. K. Jodkowski. Wydawnictwo Uniwersytetu Marii Curie-Skłodowskiej, Lublin 1986, s. 309-324.

84 Ibidem, s. 317.

${ }^{85}$ P.K. Feyerabend: Mit „nauki” $i$ jego rola $w$ społeczeństwie. W: Czy sprzeczność może być racjonalna..., s. 293.

${ }^{86}$ Ibidem, s. 296.

87 Ibidem, s. 303. 
się bowiem utrzymać $\mathrm{w}$ świetle wyników badań prowadzonych w ramach studiów nad nauką i technologią. To jednak temat na osobną pracę.

\section{Bibliografia}

Barnes B., Bloor D.: Mocny program socjologii wiedzy. Przeł. Z. Jankiewicz. Wydawnictwo Instytutu Filozofii i Socjologii Polskiej Akademii Nauk, Warszawa 1993.

Derra A.: Specyficzny kontekst społeczny i jego rola w teorii znaczenia późnego Wittgensteina. „Kognitywistyka i Media w Edukacji” 2007, nr 1/2, s. 133-141.

Feyerabend P.K.: Jak być dobrym empirystą? Przeł. K. Zamiara. Wydawnictwo Naukowe PWN, Warszawa 1979.

Feyerabend P.K.: Jak obronić społeczeństwo przed nauka? W: Czy sprzeczność może być racjonalna. Red. K. Jodkowski. Wydawnictwo Uniwersytetu Marii Curie-Skłodowskiej, Lublin 1986, s. 309-324.

Feyerabend P.K.: Mit „nauki” i jego rola w spoleczeństwie. W: Czy sprzeczność może być racjonalna. Red. K. Jodkowski. Wydawnictwo Uniwersytetu Marii Curie-Skłodowskiej, Lublin 1986, s. 292-307.

Feyerabend P.K.: Przeciw metodzie. Przeł. S. Wiertlewski. Red. nauk. przekładu K. Zamiara. Siedmioróg, Wrocław 2001.

Hanuszewicz S.: Popper a socjologia wiedzy. W: Teoretyczne podstawy socjologii wiedzy. Red. P. Bytniewski, M. Chałubiński. T. 1. Wydawnictwo Uniwersytetu Marii Curie-Skłodowskiej, Lublin 2006, s. 198-210.

Jodkowski K.: Filozofia nauki Paula K. Feyerabenda. Stadium umiarkowane. „Studia Filozoficzne" 1979, nr 11, s. 59-75.

Knorr-Cetina K.: Etnograficzne studium pracy naukowej: w strone konstruktywistycznej interpretacji nauki. W: Studia nad nauka i technologiq. Wybór tekstów. Red. E. Bińczyk, A. Derra. Tłum. M. Wróblewski. Wydawnictwo Naukowe Uniwersytetu Mikołaja Kopernika, Toruń 2014, s. 181-215.

Lakatos I.: Pisma z filozofii nauk empirycznych. Przeł. W. Sady. Wydawnictwo Naukowe PWN, Warszawa 1995.

Latour B.: Nadzieja Pandory. Eseje o rzeczywistości w studiach nad nauka. Przeł. K. Abriszewski. Wydawnictwo Naukowe Uniwersytetu Mikołaja Kopernika, Toruń 2013.

Latour B., Woolgar S.: Życie laboratoryjne: konstruowanie faktów naukowych. Tłum. K. Abriszewski. Narodowe Centrum Kultury, Warszawa 2020.

Leszczyński D., Szlachcic K.: Wprowadzenie do francuskiej filozofii nauki. Od Comte'a do Foucaulta. Wydawnictwo Uniwersytetu Wrocławskiego, Wrocław 2003. 
Mączka D.: Amodernistyczna filozofia Paula Feyerabenda. „Hybris” 2018, $\mathrm{nr}$ 41, s. 77-97. Pobrano z: https://ruj.uj.edu.pl/xmlui/bitstream/handle/ item/56562/maczka_amodernistyczna_filozofia_paula_\%20feyerabenda_2018. pdf?sequence $=3 \&$ isAllowed $=y$ [23.11.2021].

Mączka D.: Mit i mity w filozofii Paula Feyerabenda. „Analiza i Egzystencja” 2017, nr 39, s. 97-116. https://doi.org/10.18276/aie.2017.39-06.

Mączka D.: Rola filozofii nauki w ujęciu Paula Feyerabenda. W: Episteme. O poznaniu filozoficznym i naukowym. Red. K. Bałękowski, P. Wiatr. Wydawnictwo Naukowe TYGIEL, Lublin 2016, s. 164-184.

Michalska A.: Nauka - dyskurs czy propaganda? Kampania Galileusza w świetle anarchizmu Paula Feyerabenda oraz koncepcji dziatania komunikacyjnego Jurgena Habermasa. „Argument” 2012, nr 2, s. 377-396. Pobrano z: https:// argument.up.krakow.pl/article/download/6353/5881/ [23.11.2021].

Popper K.R.: Logika odkrycia naukowego. Przeł. U. Niklas. Wyd. 2. Wydawnictwo Naukowe PWN, Warszawa 2002.

Popper K.R.: Nędza historycyzmu. Przeł. S. Amsterdamski. Wydawnictwo Naukowe PWN, Warszawa 1999.

Popper K.R.: Spoleczeństwo otwarte i jego wrogowie. T. 1: Urok Platona. Przeł. H. Krahelska. Oprac. A. Chmielewski. Wyd. 2. Wydawnictwo Naukowe PWN, Warszawa 1993.

Popper K.R.: Spoleczeństwo otwarte i jego wrogowie. T. 2: Wysoka fala proroctw. Hegel, Marks i następstwa. Przeł. H. Krahelska. Oprac. A. Chmielewski. Wydawnictwo Naukowe PWN, Warszawa 1993.

Sady W.: Spór o racjonalność naukowa. Od Poincarégo do Laudana. Wyd. 2., rozsz. i popr. Wydawnictwo Naukowe Uniwersytetu Mikołaja Kopernika, Toruń 2013.

Sady W.: Wittgenstein. Życie i dzieto. Daimonion, Lublin 1993.

Siemek M.: Myśl drugiej połowy XX wieku. W: Drogi wspótczesnej filozofii. Wybrał i wstępem opatrzył M.J. Siemek. Przeł. S. Cichowicz et al. Czytelnik, Warszawa 1978, s. 5-48.

Whorf B.L.: Język, myśl i rzeczywistość. Przeł. T. Hołówka. Wydawnictwo KR, Warszawa 2002.

Wittgenstein L.: Dociekania filozoficzne. Przeł. B. Wolniewicz. Wydawnictwo PWN, Warszawa 2000.

Wittgenstein L.: O pewności. Przeł. B. Chwedeńczuk. Wydawnictwo KR, Warszawa 2001.

Wittgenstein L.: Uwagi o „Złotej Gałęzi” Frazera. Przeł. A. Orzechowski. Instytut Kultury, Warszawa 1998.

Jakub Lampart - student pierwszego roku filozofii na Uniwersytecie Jagiellońskim, interesuje się głównie filozofią nauki i socjologią wiedzy. Niniejszy artykuł stanowi jego pierwszą publikację naukową. 